inositol trisphosphate concentration".

The data in this report are clear-cut, and are based on an elegant and novel approach using a purpose-built chemical variant of $\operatorname{InsP}_{3}$. But the authors' conclusions are not the only, or necessarily the most likely, interpretation of their results.

One alternative is that InsPS acts as a $_{3}$ stimulus for a small release of intracellular $\mathrm{Ca}^{2+}$ to raise intracellular calcium concentration to a level below the threshold for increased chloride conductance, but enough to activate, or increase the basal activity of, phospholipase $\mathrm{C}$ and hence generate endogenous $\operatorname{InsP}_{3}$. The stage would then be set for intracellular $\mathrm{Ca}^{2+}$ spiking based on feedback between $\mathrm{InsP}_{3}$ induced $\mathrm{Ca}^{2+}$ discharge and $\mathrm{Ca}^{2+}$-enhanced phospholipase $\mathrm{C}$ activity as modelled by Meyer and Stryer ${ }^{2}$. We know from Fig. 1 of Wakui et al. ${ }^{1}$ that their cells are capable of generating spikes in response to acetylcholine, a ligand acting via the inositol lipid signal pathway.

The analysis of Wakui et al. is based on the idea that a stimulus cannot be part of the feedback generating a train of spikes if a steady application of that stimulus evokes spikes. But this is like arguing that generation of a train of action potentials in a motor neuron cannot be based on inward currents and membrane depolarization, because such trains can be initiated experimentally by application of depolarizing current via a microelectrode. Wakui et al. seem to have neglected the possibility that InsPS ${ }_{3}$ could have activated the cells to generate their own InsP (and possibly also $\operatorname{InsP}_{4}$ ). We need measurements of inositol phosphates, in single cells on the appropriate time scale, before deciding whether they do or do not fluctuate during intracellular $\mathrm{Ca}^{2+}$ oscillations ${ }^{3}$.

TIMOTHY J. RINK Smith Kline \& French Research Limited, The Frythe, Welwyn, Hertfordshire AL6 9AR, UK

Petersen et al. RePLy-Rink's attempt to resurrect the theory that pulsatile inositol $(1,4,5)$ trisphosphate $\left(\mathrm{InsP}_{3}\right)$ production is responsible for intracellular $\mathrm{Ca}^{2+}$ spikes involves a complicated explanation and an unlikely assumption. Our data ${ }^{1}$ show that inositol $(1,4,5)$ trisphosphorothioate (InsPS $)_{3}$ evokes the same effect as InsP $P_{3}$. Because it has been clearly shown that InsPS, although about 3-5fold less potent than InsP $\mathbf{P}_{3}$, is nevertheless a full agonist for the release of $\mathrm{Ca}^{2+}$ from intracellular stores ${ }^{4.5}$, why then assume that in our experiments InsPS evokes a $_{3}$ "small release of intracellular $\mathrm{Ca}^{2+}$ " and that its demonstrated effect is due to the secondary production of $\operatorname{InsP}_{3}$ ?

The mechanism postulated by Rink is $\mathrm{Ca}^{2+}$-activation of phospholipase $\mathrm{C}$. But in pancreatic acinar cells this process seems to be of little significance, as secretagogueevoked $\mathrm{InsP}_{3}$ production is independent of changes in intracellular $\mathrm{Ca}^{2+}$ concentration $^{6}$ and stimulation of intact cells with the $\mathrm{Ca}^{2+}$ ionophone $\mathrm{A} 23187$ results in very little secretion unless coupled with either a muscarinic agent or an activator of protein kinase $\mathrm{C}$ (ref. 7). These results indicate that a $\mathrm{Ca}^{2+}$ signal alone cannot elicit significant phosphatidyl inositol $(4,5)$ bisphosphate hydrolysis and therefore diacylglycerol production.

Our data ${ }^{1}$ do seem to show that InsPS 3 is perhaps about 2-3-fold more potent relative to $\mathrm{InsP}_{3}$ than had been expected on the basis of experiments in permeabilized cells ${ }^{4,5}$, but this can be explained very simply, as $\mathrm{InsP}_{3}$ would be subject to breakdown in our cells, whereas this would not be the case for InsPS . $_{3}$

O.H. Petersen M. WAKUI

MRC Secretory Control Research Group, Physiological Laboratory,

University of Liverpool,

PO Box 147 ,

Liverpool L69 3BX, UK

Department of Chemistry,

B.V.L. POTTER

University of Leicester,

Leicester LE1 7RH, UK

1. Wakui, M., Potter, B.V.L. \& Petersen, O.H. Nature 339, 317-320 (1989)

2. Meyer, T. \& Stryer, L. Proc. natn. Acad. Sci. U.S.A. $\mathbf{8 5}$

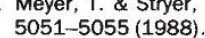

3. Rink, T.J. \& Jacob, R. Trends Neurosci. 12, 43-46 (1989) 4. Taylor, C.W., Berridge, M.J., Cook, A.M. \& Potter, B.V.L. Biochem. J. 259, 645-650 (1989).

Strupish, J., Cooke, A. M., Potter, B. V. L., Gigg, R. \& Nahorski, S. R. Biochem. J. 253, 901-905 (1988).

6. Streb, H., Heslop, J.P., Invine, R.F., Schulz, I. \& Berridge M.J. J. biol. Chem. 260, 7309-7315 (1985)

. De Pont, J.J.H.H.M. \& Fleuren-Jakobs, A.M.M. FEBS Lett De Pont, J.J.H.H.M.
170, 64-68 (1984)

\section{Amylin hormone}

SIR-Betsholtz et al. ${ }^{1}$ have recently commented on our use of the name amylin ${ }^{2,3}$ for the newly discovered 37-amino-acid peptide hormone which is found in $\beta$-cells of the pancreatic islets of Langerhans and probably secreted along with insulin. This peptide has also been termed $\mathrm{DAP}^{4}$ (diabetes-associated peptide). The primary amino-acid sequence of amylin is known, its carboxy terminus is amidated, and it is a potent down-regulator of both basal and insulin-stimulated glucose uptake and glycogen synthesis in mammalian skeletal muscle in vitro ${ }^{2,3}$.

Betsholtz and colleagues have isolated from insulinoma-associated amyloid a

1. Betsholtz, C., Johnson, K.H. \& Westermark, P. Nature 338 211 (1989).

2. Cooper, G.J.S. et al. Proc. natn. Acad. Sci USA 85, 7763 7766 (1988).

3. Leighton, B. \& Cooper, G.J.S. Nature 335, 632-635 (1988).

4. Cooper, G.J.S. et al. Proc. natn. Acad. Sci. USA 84, 8628 8632 (1987)

5. Westermark, P., Wernstedt, C., Wilander, E. \& Sletton, K Biochem. biophys. Res. Comm. 140, 827-831 (1986).

Westermark, P. et al. Proc. natn. Acad. Sci. USA 84, 3881-3885 (1987)

7. Yoshioka, K. et al. Molec. biol. Med. 3, 319 (1986). peptide called IAP $^{5}$ (insulinoma amyloid peptide) or IAPP $^{6}$ (islet or insulinoma amyloid polypeptide) which is similar to amylin in primary sequence. The equivalence of IAP/IAPP and amylin remains to be proved, however, as the complete sequence and structure of IAP/IAPP have not been determined, nor has any functional activity been reported for either. It should be noted that a change at a single amino-acid locus may result in a variant, amyloidogenic protein which is able to form amyloid deposits ${ }^{7}$.

GARTH J.S. COOPER ANTHONY C. WILLIS

MRC Immunochemistry Unit

Department of Biochemistry,

University of Oxford,

Oxford OX1 3QU, UK

Department of Biochemistry,

BRENDAN LEIGHTON

University of Oxford,

Oxford OX1 3QU, UK

\section{Radiation limits}

SIR-Robin Russell Jones ${ }^{1}$ argues that public radiation dose limits should be reduced to 0.2 millisievert $(\mathrm{mSv})$ per year. This refers to the additional radiation doses to the public from industrial sources. The limit is currently $1 \mathrm{mSv}$ a year if exposure is prolonged, and the UK National Radiological Protection Board has recommended reduction to $0.5 \mathrm{mSv}$. In practice, the average additional dose due to such sources is $0.001 \mathrm{mSv}$ a year, and the highest dose to the public recorded in 1987 was $0.33 \mathrm{mSv}$, with very few members receiving more than $0.1 \mathrm{mSv}$ (ref. 2).

These doses are very low compared with the total exposure to radiation ${ }^{3}$. The average annual UK dose is $2.5 \mathrm{mSv}$, and $7.8 \mathrm{mSv}$ in Cornwall. The highest doses, which can exceed $50 \mathrm{mSv}$ a year, are due to indoor radon, and the highest artificial doses are due to medical exposures, which average $0.3 \mathrm{mSv}$ a year. Both of these could be reduced by remedial measures ${ }^{4,5}$.

The low doses from industrial sources have been achieved by heavy expenditure. It is time to concentrate our radiological protection measures on that part of the population at highest risk rather than to attempt to reduce even further the small additional doses to groups which are already at very low risk. Exposures to ionizing radiation should be considered in total.

L.E.J. ROBERTS

School of Environmental Sciences,

University of East Anglia,

Norwich NR4 7TJ, UK

1. Russell Jones, R. Nature 339, 20 (1989).

2. Hunt, G. J. Radioactivity in Surface and Coastal Waters of the British Isles, 1987 (MAFF, Lowestoft, 1988).

3. Clarke, R.H. \& Southwood, T.R.E. Nature 338, 197 (1989).

4. Exposure to Radon Daughters in Dwellings NRPB-GS6 (National Radiological Protection Board, Chilton, 1987).

5. Russell, J.G.B. \& Webb, G.A.M. Brit. J. Radiol. 60, 681 (1987).

NATURE $\cdot$ VOL $340 \cdot 27$ JULY 1989 